einstein

Official Publication of the Instituto Israelita

de Ensino e Pesquisa Albert Einstein

ISSN: 1679-4508 | e-ISSN: 2317-6385

\title{
Effect of physical activity on asthma control in schoolchildren
}

\section{Efeito da atividade física no controle da asma em escolares}

\author{
Ana Paula dos Santos ${ }^{1}$, Márcio Júnior Strassburger ${ }^{1}$, Cristian Roncada² ${ }^{2}$ Renato Tetelbom Stein ${ }^{3}$, \\ Paulo Márcio Pitrez ${ }^{3}$, Simone Zeni Strassburger ${ }^{1}$ \\ 1 Universidade Regional do Noroeste do Estado do Rio Grande do Sul, ljuí, RS, Brazil. \\ ${ }^{2}$ Centro Universitário da Serra Gaúcha, Caxias do Sul, RS, Brazil. \\ ${ }^{3}$ Pontifícia Universidade Católica do Rio Grande do Sul, Porto Alegre, RS, Brazil.
}

DOI: 10.31744/einstein_journal/2020A04936

\section{ABSTRACT}

Objective: To investigate the effect of levels of physical activity on asthma control in children. Methods: A cross-sectional study, including public school students aged 8 to 12 years, of both sexes, with asthma, from a capital and a medium-sized cities in Southern Brazil. At home, the students answered the questionnaire on levels of physical activity and disease control. Results: A total of 482 schoolchildren with asthma participated in the study, with mean age of $10.9 \pm 2.2$ years, and 253 (52\%) were girls. Regarding disease control, 50\% had controlled asthma, and $67 \%$ were considered sedentary. Schoolchildren with controlled asthma were more active than those with uncontrolled asthma $(p=0.032)$. Active schoolchildren were more likely to have asthma controlled (OR=1.5; 95\% Cl: 1.04-2.25). Conclusion: The results demonstrated an association between physical activity levels and asthma control. More active schoolchildren were more likely to have asthma controlled.

Keywords: Asthma; Exercise; Sedentary behavior; Child; Adolescent

\section{RESUMO}

How to cite this article:

Santos AP, Strassburger MJ, Roncada C, Stein RT, Pitrez PM, Strassburger SZ. Effect of physical activity on asthma control in schoolchildren. einstein (São Paulo). 2020;18:eA04936. http://dx.doi.org/ 10.31744/einstein_journal/2020A04936

Corresponding author:

Simone Zeni Strassburger

Rua do Comércio, 3.000 - Bairro Universitário

Zip code: 98700-000 - ljuí, RS, Brazil

Phone: (55 55) 3332-0461

E-mail: simone.s@unijui.edu.br

Received on:

Jan 9, 2019

Accepted on:

June 25, 2019

Conflict of interest:

none.

Copyright 2019

\section{(c) BY}

This content is licensed

under a Creative Commons

Attribution 4.0 International License.

Objetivo: Investigar o efeito dos níveis de atividade física no controle da asma em crianças. Métodos: Estudo transversal, incluindo escolares da rede pública, de 8 a 12 anos, de ambos os sexos, com asma, de uma capital e de uma cidade de porte médio da Região Sul do Brasil. Os escolares responderam, em seus domicílios, um questionário de níveis de atividade física e de controle da doença. Resultados: Participaram da pesquisa 482 escolares com asma, com média de idade de 10,9 92,2 anos, e $253(52 \%)$ eram meninas. Quanto ao controle da doença, $50 \%$ apresentavam asma controlada e $67 \%$ foram considerados sedentários. 0s escolares com asma controlada foram mais ativos do que os com asma não controlada $(p=0,032)$. Os escolares ativos tiveram mais chance de ter a asma controlada ( $\mathrm{RC}=1,5$; IC95\%: 1,04-2,25). Conclusão: 0 s resultados demonstraram associação entre os níveis de atividade física e controle da asma. Os escolares mais ativos apresentaram mais chance de ter a asma controlada.

Descritores: Asma; Exercício; Comportamento sedentário; Criança; Adolescente

\section{INTRODUCTION}

Asthma is considered the most prevalent chronic disease in the pediatric age groups, affecting from 8.7 to $30.8 \%$ of this population in different Latin American countries. ${ }^{(1)}$ Due to its multifactorial etiology, compliance with treatment and control of the disease can be influenced by various factors. ${ }^{(1,2)}$ Absence of adequate control results in exacerbations and hospitalizations. In Brazil, there are approximately 110 hospitalizations for every 100 thousand 
inhabitants, and the mean hospital mortality rate is $0.46 \% .^{(3,4)}$

Currently, interest is growing in elucidating the influence of some factors, such as exposure to passive smoking, socioeconomic factors, ${ }^{(5)}$ obesity, and levels of physical activity in the control of asthma. ${ }^{(6)}$ Many investigations around the world have addressed control of the disease, and physical activity seems to play an important role in the management of asthma. ${ }^{(7)}$

Reduction in the number of exacerbations and hospital admissions in asthmatic individuals with higher levels of physical activity has been reported, ${ }^{(8)}$ besides others benefits, such as improved pulmonary function, control of inflammatory mediators, increase in aerobic capacity, and decrease in occurrence of bronchospasm induced by exercise in asthmatic individuals..$^{(9,10)}$

Maintenance of asthma control helps in reducing the risk of exacerbations and hospitalizations, decreasing the use of health resources, and consequently, of costs of the disease (currently R $\$ 1.984,17 /$ patient-year). ${ }^{(11)}$ However, scientific production regarding the relation between the levels of physical activity and asthma control in children and adolescents is still scarce, and the existing results are controversial. ${ }^{(12,13)}$

\section{OBJECTIVE}

To investigate the effect of the levels of physical activity on the control of asthma.

\section{METHODS}

This is an observational study about the prevalence and clinical characteristics of asthma in schoolchildren aged between 8 and 16 years, at a public education network. The study occurred in two distinct locations, and was conducted with schoolchildren of an industrialized metropolis (Porto Alegre, State of Rio Grande do Sul RS), and schoolchildren from a medium-size city in the south of the country (Ijuí, a municipality located in the Northeast of the state of RS). Data were collected during a simultaneous period (2013-2014), applying the same cross-sectional design, in addition to the use of the same instruments for collection and analysis of the data. In Porto Alegre, 2,500 schoolchildren were evaluated, while in Ijuí, 1,688 schoolchildren were assessed. The study was submitted to the Research Ethics Committee of both locations, and was approved by Consolidated Opinion No. 73583/2012, CAAE: 03448512.0.0000.5336, and 131568/2012, CAAE: 08035412.5.0000.5336.

Data collection of both studies was organized based on two distinct phases. The first phase consisted of the selection of schoolchildren with asthma, based on the application of the instrument for epidemiological diagnosis of asthma, according to the International Study of Asthma and Allergies in Childhood (ISAAC) protocol. ${ }^{(14)}$ The instrument is composed of four questions that investigate medical diagnosis of asthma at any time of life, asthma crises over the previous 12 months, and at any time of life, in addition to the use of medications for asthma over the last 12 months. For the schoolchildren to be characterized as asthmatic, the four questions needed to have positive answers.

During the second phase, schoolchildren classified with asthma, as of triage of the first phase, answered control questionnaires about asthma and level of physical activity. Control of the disease was evaluated by means of the Asthma Control Test (ACT), with cut-off point at $\geq 20$ points for categorization of controlled asthma. ${ }^{(15)}$ The levels of physical activity were investigated by a specific protocol, which calculated the weekly amount of time (in minutes) dedicated to physical activities. Patients were classified as sedentary schoolchildren if they had a sum of less than 300 minutes a week of reported physical activity. ${ }^{(16)}$

Analysis of the economic classification was based on the questionnaire Critério de Classificação Econômica Brazil (CCEB) [Brazil Economic Classification Criteria] of the Associação Brasileira de Empresas de Pesquisa (ABEP) [Brazilian Association of Research Companies].(17)

For statistical analysis, the continuous variables are presented as mean and standard deviation, or median and interquartile range, according to the symmetry of the variables. The categorical variables are presented as absolute and relative frequencies. For comparison of the variables with normal distribution among groups, Student's $t$ test was applied, and Mann-Whitney's test was used for variables with abnormal distribution. Relations between the categorical variables were tested by the $\chi^{2}$ method, and the odds ratio between the variables was tested by the odds ratio method (OR). Differences between groups or analyses of outcomes were considered significantly different, with $p<0.05$. All the analyses were conducted using the Software (SPSS), version 18 (Chicago, USA).

\section{| RESULTS}

A total of 482 schoolchildren with asthma participated in the study (359 in Porto Alegre and 123 in Ijuí), with a mean age of $10.9 \pm 2.2$ years, and 253 (52\%) were girls. As to socioeconomic classification, 263 (75\%) belonged to classes $\mathrm{C}, \mathrm{D}$, and $\mathrm{E}$. As to control of asthma, $50.2 \%$ of participants presented with control of the disease. 
The prevalence of sedentary behavior was $67.8 \%$; and $73.7 \%$ reported spending more than 2 hours daily in front of screens TV/cell phone/computer. The characterization data of the participating schoolchildren are shown on table 1.

Table 2 demonstrates the differences for the variables among schoolchildren, as per the level of physical activity. When we compare the schoolchildren who were asthmatic, active, and sedentary, we observed no difference between the groups for economic and screen time classification. Nevertheless, the frequency of active boys $(64.5 \%)$ was greater when compared to that of girls $(\mathrm{p}<0.001)$, and schoolchildren with controlled asthma were more active (57.4\%) than those with noncontrolled asthma $(\mathrm{p}=0.032)$.

Table 1. Characterization of the schoolchildren with asthma

\begin{tabular}{ll}
\hline Characteristic & \\
\hline Age & $10.9 \pm 2.2$ \\
\hline Female & $253(52.4)$ \\
Socioeconomic classification & \\
$\quad$ A and B & $119(24.7)$ \\
C, D and E & $363(75.3)$ \\
Controlled asthma & $242(50.2)$ \\
Sedentary behavior & $327(67.8)$ \\
Screen time of more than 2 hours daily & $355(73.7)$ \\
\hline Results expressed as mean + standard deviation or $n(\%)$. &
\end{tabular}

Table 2. Characterization of the variables according to the level of physical activity of the schoolchildren

\begin{tabular}{|c|c|c|c|}
\hline Characteristic & $\begin{array}{l}\text { Active } \\
n=155\end{array}$ & $\begin{array}{c}\text { Sedentary } \\
n=327\end{array}$ & p value \\
\hline \multicolumn{4}{|l|}{ Sex } \\
\hline Female & $55(35.5)$ & $188(57.5)$ & $<0.001^{*}$ \\
\hline Male & $100(64.5)$ & $139(42.5)$ & \\
\hline \multicolumn{4}{|l|}{ Economic classification } \\
\hline$A$ and $B$ & $45(29.0)$ & $74(22.6)$ & 0.279 \\
\hline$C, D$ and $E$ & $110(71.0)$ & $253(77.4)$ & \\
\hline \multicolumn{4}{|l|}{ Control of asthma } \\
\hline Controlled & $89(57.4)$ & $153(46.8)$ & $0.032^{*}$ \\
\hline Non-controlled & $66(42.6)$ & $174(53.3)$ & \\
\hline \multicolumn{4}{|l|}{ Screen time } \\
\hline More than 2 hours a day & $110(71.0)$ & $245(74.9)$ & 0.377 \\
\hline Less than 2 hours a day & $45(29.0)$ & $82(25.1)$ & \\
\hline
\end{tabular}

Results expressed as $n(\%)$. ${ }^{*} p<0.05\left(\chi^{2}\right.$ test)

Table 3. Relation of odds between asthma control and the variables assessed

\begin{tabular}{lc} 
& OR (95\%CI) \\
\hline Screen time & $1.054(0.703-1.581)$ \\
Sex & $1.142(0.799-1.633)$ \\
Level of physical activity & $1.534(1.043-2.255)^{*}$ \\
Socioeconomic classification & $1.265(0.835-1.916)$ \\
\hline${ }^{*}$ OR significant OR: odds ratio; 95\%Cl: 95\% confidence interval. &
\end{tabular}

When we analyzed the effect of physical activities on control of asthma, as per table 3, we found that active schoolchildren had a greater chance of presenting with controlled asthma $(\mathrm{OR}=1.5$; 95\%CI: 1.04-2.25). Screen time, sex, and the economic classification presented no significant relation with control of the disease.

\section{DISCUSSION}

Recent studies have been conducted with the objective of knowing the impact that regular practice of physical activities can have on asthma. The present study evaluated the risk of this variable interfering in the control of the disease, resulting in physically more active schoolchildren presenting with a better control of asthma, thus reflecting a greater odds ratio of control of the disease.

There are few studies involving the pediatric age range aimed to evaluate the effect of the regular practice of physical activities on asthma control. Matsunaga et al., ${ }^{(12)}$ investigated asthmatic children and adolescents, and correlated the level of control of asthma and levels of physical activity during the previous week, and found no significant associations between them. In another study, it was found that those who were physically active were also more inclined to report symptoms of asthma during the day and night awakenings. ${ }^{(13)}$

A study done with 643 adult asthmatics reached results similar to ours, considering that the total time of habitual physical activities was related to the control of the asthma, and the probability of obtaining good control of the disease was twice as high in active asthmatics. Its findings highlighted that in the highest quartile of physical activity were almost 2.5 times more controlled $(\mathrm{OR}=2.47)$ in comparison with those who did not get involved in any type of physical activity. ${ }^{(18)}$

In another study involving 61 adults with severe asthma, it was noted that higher indices of physical activities and lower levels of sedentary behavior are associated with a better capacity for exercise, better control of inflammatory mediators, and better control of the disease. ${ }^{(19)}$

Despite recent studies pointing towards the regular practice of physical activities as an important factor for asthma control, some results still seem controversial. Verlaet et al., ${ }^{(20)}$ found the regular practice of moderate intensity physical activities was considered a factor for the control of asthma in men, while the regular practice of rigorous intensity physical activities, increased the risk of uncontrolled asthma in women. The study by Lövström et al., ${ }^{(21)}$ reported women with high levels of regular physical activity, as compared to moderate levels 
of activity, would have less control of asthma. Thus, it seems that the practice of regular physical activities with moderate intensity would be more protective against the symptoms of asthma than activities with vigorous intensity. Del Giacco et al., ${ }^{(22)}$ reinforced the fact that moderate levels of regular physical activities have a positive effect on the control of asthma.

Therefore, physical inactivity may be associated with a low index of control of the disease. Additionally, asthmatic children tend to be more physically inactive when compared to healthy children. ${ }^{(23,24)}$

We identified a high rate of sedentary behavior (67.8\%) among the schoolchildren of the present study. Roncada et al. ${ }^{(25)}$ found a similar result: $67.2 \%$ of asthmatic children were sedentary. Teng et al., ${ }^{(26)}$ one the other hand, noted greater physical inactivity (less than 300 minutes a week) in girls when compared to boys, corroborating the results of the present study, according to which the frequency of active boys was greater when compared to girls $(\mathrm{p}<0.001)$.

Remaining for a prolonged time in front of screens is considered detrimental to health. ${ }^{(27)}$ In the present study, $73 \%$ of asthmatic individuals remained more than 2 hours a day in screen time. Willeboordse et al., ${ }^{(28)}$ found lower levels of physical activity in school-aged children who spent more sedentary minutes in screen time than being physically active. Physical inactivity is one of the primary risk factors for morbidity and mortality, has great influence on the prevalence of noncommunicable diseases, and it is considered a serious public health problem. ${ }^{(29)}$

Asthma control is essential for a good quality of life, and is considered the primary objective of treatment. ${ }^{(1)}$ Of the study schoolchildren, only $50 \%$ presented with controlled asthma. Gazzotti et al., ${ }^{(30)}$ also noted low levels of controlled asthma (9.3\%) and high levels of partially controlled $(56.5 \%)$ and non-controlled $(32.2 \%)$ asthma. In addition to the lack of control of asthma, the disease is associated with an increased number of hospitalizations.

Some limitations should be considered in the present study. The scarcity of other studies that related the outcome variables in the pediatric population hindered a more consistent discussion. The population of schoolchildren originated from two studies with the same methodology, but carried out in different cities, with distinct regional characteristics. This is understood as not disqualifying the analysis of the outcome variables investigated. The test applied, such as ACT and the level of physical activity, are validated, although selfreported, containing possible biases of answers inherent to this type of tool. The instrument utilized did not include questions relative to the intensity of the physical activities, preventing the analysis of outcomes for this variable. Finally, since this is a cross-sectional design, it is impossible to define the exact direction of the relation between control of asthma and physical activity. Our results probably reflect the possibility that those with better asthma control were engaged in more physical activities.

\section{CONCLUSION}

The results demonstrate an association between the levels of satisfactory physical activity and acceptable levels of asthma control. The most active schoolchildren presented with higher odds ratios of having controlled asthma. Additionally, the sedentary lifestyle proved to be present in a large part of the study schoolchildren. We understand that it is necessary to expand the studies about the possible effects of regular practice of physical activities for control of asthma in this age range. Moreover, it is important to further understand this regular practice as a form of supporting treatment for children and adults with asthma, seeking to improve the control rates of the disease.

\section{AUTHORS' INFORMATION}

Santos AP: http://orcid.org/0000-0002-0964-9370

Strassburger MJ: http://orcid.org/0000-0001-9411-3230

Roncada C: http://orcid.org/0000-0003-3782-4911

Stein RT: http://orcid.org/0000-0003-0269-0757

Pitrez PM: http://orcid.org/0000-0001-7319-1133

Strassburger SZ: http://orcid.org/0000-0001-9655-8807

\section{REFERENCES}

1. Bateman ED, Hurd SS, Barnes PJ, Bousquet J, Drazen JM, FitzGerald $\mathrm{JM}$, et al. Global strategy for asthma management and prevention: GINA executive summary. Eur Respir J. 2008;31(1):143-78. Erratum in: Eur Respir J. 2018;51(2).

2. Solé D, Aranda CS, Wandalsen GF. Asthma: epidemiology of disease control in Latin America-short review. Asthma Res Pract. 2017;3(1):4. Review.

3. Bousquet J, Bousquet PJ, Godard P, Daures JP. The public health implications of asthma. Bull World Health Organ. 2005;83(7):548-54.

4. Cardoso TA, Roncada C, Silva ER, Pinto LA, Jones MH, Stein RT, et al. The impact of asthma in Brazil: a longitudinal analysis of data from a Brazilian national database system. J Bras Pneumol. 2017;43(3):163-8.

5. Blic J, Boucot I, Pribil C, Robert J, Huas D, Marguet C. Control of asthma in children: still unacceptable? A French cross-sectional study. Respir Med. 2009;103(9):1383-91.

6. Kinchoku VM, Oliveira IS, Watanabe LA, Fomin ABF, Castro AP, Jacob CM, et al. Fatores associados ao controle da asma em pacientes pediátricos em centro de referência. Rev Paul Pediatr. 2011;29(4):591-8.

7. Heikkinen SA, Mäkikyrö EM, Hugg TT, Jaakkola MS, Jaakkola JJ. Effects of regular exercise on asthma control in young adults. J Asthma. 2018; 55(7):726-33 
8. Garcia-Aymerich J, Varraso R, Antó JM, Camargo CA Jr. Prospective study of physical activity and risk of asthma exacerbations in older women. Am J Respir Crit Care Med. 2009;179(11):999-1003.

9. Pakhale S, Luks V, Burkett A, Turner L. Effect of physical training on airway inflammation in bronchial asthma: a systematic review. BMC Pulm Med. 2013;13:38. Review.

10. Fanelli A, Cabral AL, Neder JA, Martins MA, Carvalho CR. Exercise training on disease control and quality of life in asthmatic children. Med Sci Sports Exerc. 2007;39(9):1474-80.

11. Mancuso CA, Choi TN, Westermann H, Wenderoth S, Wells MT, Charlson ME. Improvement in asthma quality of life in patients enrolled in a prospective study to increase lifestyle physical activity. J Asthma. 2013;50(1):103-7.

12. Matsunaga NY, Oliveira MS, Morcillo AM, Ribeiro JD, Ribeiro MA, Toro AA. Physical activity and asthma control level in children and adolescents. Respirology. 2017;22(8):1643-8.

13. Nnodum BN, McCormack MC, Putcha N, Hwang S, Paulin LM, Brigham EP, et al. Impact of Physical Activity on Reporting of Childhood Asthma Symptoms. Lung. 2017;195(6):693-8.

14. Asher MI, Montefort S, Björkstén B, Lai CK, Strachan DP, Weiland SK, Williams $\mathrm{H}$; ISAAC Phase Three Study Group. Worldwide time trends in the prevalence of symptoms of asthma, allergic rhinoconjunctivitis, and eczema in childhood: ISAAC Phases One and Three repeat multicountry cross-sectional surveys. Lancet. 2006;368(9537):733-43. Erratum in: Lancet. 2007;370(9593):1128.

15. Roxo JP, Ponte EV, Ramos DC, Pimentel L, D’Oliveira Júnior A, Cruz AA. Validação do Teste de Controle da Asma em português para uso no Brasil. J Bras Pneumol. 2010;36(2):159-166.

16. Hallal P, Bertoldi A, Gonçalves H, Victora C. Prevalência de sedentarismo e fatores associados em adolescentes de 10-12 anos de idade. Cad Saude Publica. 2006;22(6):1277-87.

17. Associação Brasileira de Empresas de Pesquisa (ABPE). Critério de Classificação Econômica Brasil 2010 [Internet]. São Paulo): ABEP; 2019 [citado 2019 Out 17]. Disponível em: http://www.abep.org/criterio-brasil

18. Bacon SL, Lemiere C, Moullec G, Ninot G, Pepin V, Lavoie KL. Association between patterns of leisure time physical activity and asthma control in adult patients. BMJ Open Respir Res. 2015;2(1):e000083.

19. Cordova-Rivera L, Gibson PG, Gardiner PA, Powell H, McDonald VM. Physical Activity and Exercise Capacity in Severe Asthma: Key Clinical Associations. J Allergy Clin Immunol Pract. 2018;6(3):814-22.
20. Verlaet A, Moreira A, Sá-Sousa A, Barros R, Santos R, Moreira P, et al. Physical activity in adults with controlled and uncontrolled asthma as compared to healthy adults: a cross-sectional study. Clin Transl Allergy. 2013;3(1):1.

21. Lövström L, Emtner M, Alving K, Nordvall L, Borres MP, Janson C, et al. High levels of physical activity are associated with poorer asthma control in young females but not in males. Respirology. 2016;21(1):79-87.

22. Del Giacco SR, Firinu D, Bjermer L, Carlsen KH. Exercise and asthma: an overview. Eur Clin Respir J. 2015;2:27984.

23. Lam KM, Yang YH, Wang LC, Chen SY, Gau BS, Chiang BL. Physical Activity in School-Aged Children with Asthma in an Urban City of Taiwan. Pediatr Neonatol. 2016;57(4):333-7.

24. van 't Hul AJ, Frouws $S$, van den Akker E, van Lummel R, StarrenburgRazenberg A, van Bruggen A, et al. Decreased physical activity in adults with bronchial asthma. Respir Med. 2016;114:72-7.

25. Roncada C, de Oliveira SG, Cidade SF, Sarria EE, Mattiello R, Ojeda BS, et al. Burden of asthma among inner-city children from Southern Brazil. J Asthma. 2016;53(5):498-504.

26. Teng YK, Huang JL, Yeh KW, Fu LS, Lin CH, Ma WF, et al. Influential factors of insufficient physical activity among adolescents with asthma in Taiwan. PloS One. 2014;9(12):e116417.

27. LeBlanc AG, Katzmarzyk PT, Barreira TV, Broyles ST, Chaput JP, Church TS, Fogelholm M, Harrington DM, Hu G, Kuriyan R, Kurpad A, Lambert EV, Maher C, Maia J, Matsudo V, Olds T, Onywera V, Sarmiento OL, Standage M, TudorLocke C, Zhao P, Tremblay MS; ISCOLE Research Group. Correlates of Total Sedentary Time and Screen Time in 9-11 Year-Old Children around the World: the International Study of Childhood Obesity, Lifestyle and the Environment. PLoS One. 2015;10(6):e0129622.

28. Willeboordse $M$, van de Kant $K D$, van der Velden $C A$, van Schayck $C P$, Dompeling E. Associations between asthma, overweight and physical activity in children: a cross-sectional study. BMC Public Health. 2016;16:919.

29. World Health Organization (WHO). Global Recommendations on Physical Activity for Health [Internet]. Geneva: WHO; 2010 [cited 2019 June 24]. Available from: https://www.who.int/dietphysicalactivity/global-PA-recs-2010.pdf

30. Gazzotti MR, Nascimento OA, Montealegre F, Fish J, ardim JR. Level of asthma control and its impact on activities of daily living in asthma patients in Brazil. J Bras Pneumol. 2013;39(5):532-8. 